\title{
Water balance in pediatric nephrology: construction of a Standard Operating Procedure
}

\author{
Balanço hídrico na nefrologia pediátrica: construção de um Procedimento Operacional Padrão \\ Balance hídrico en la nefrología pediátrica: construcción de un Procedimiento Operativo Estándar
}

\section{Priscila Pereira de Souza Gomes', Francisca Elisângela Teixeira Lima', Patrícia Rebouças Araújo", Maria Rosivy de Oliveira'", Edgla Graciela Ferreira Moreira de Brito', Jéssica Lourenço Carneiro', Luana Farias Lima', Natália Parla Rodrigues Batalha Andrade"II}

\author{
'Escola de Saúde Pública do Ceará. Fortaleza, Ceará, Brazil. \\ "Universidade Federal do Ceará, Health Sciences Centre. Fortaleza, Ceará, Brazil. \\ "' Universidade Estadual do Ceará. Fortaleza, Ceará, Brazil.
}

How to cite this article:

Gomes PPS, Lima FET, Araújo PR, Oliveira MR, Brito EGFM, Carneiro JL, et al. Water balance in

pediatric nephrology: construction of a Standard Operating Procedure. Rev Bras Enferm [Internet]. 2018;71(Suppl 3):1404-11.

[Thematic Issue: Health of woman and child] DOI: http://dx.doi.org/10.1590/0034-7167-2017-0045

Submission: 03-15-2017 Approval: 11-25-2017

\begin{abstract}
Objective: To construct a Standard Operating Procedure (SOP) about the water balance, to be used by the health team in the care of children hospitalized in a pediatric nephrology unit. Method: The study was carried out in two stages: integrative review of the literature for the development of SOP and validation by specialists. The search for literature occurred in the electronic databases PUBMED, SCOPUS, LILACS, BDENF. After the bibliographic survey the construction of the SOP was performed, which was evaluated by specialists. The analysis was performed by calculating the Content Validity Index (CVI). Results: nine studies were selected as results of the integrative review. The sample of specialists was composed of nine professionals. The study was evaluated in six items, five of which presented $\mathrm{CVI}=1$ and one obtained $\mathrm{CVI}=0.77$. Conclusion: the evaluation of specialists culminated in the validation of SOP, suggesting changes that were accepted and discussed with the literature.
\end{abstract}

Descriptors: Water Balance; Hydro Electrolytic Balance; Nursing; Protocols; Pediatrics.

\section{RESUMO}

Objetivo: construir um Procedimento Operacional Padrão (POP) acerca do balanço hídrico, para ser utilizado pela equipe de saúde no cuidado à criança internada em uma unidade de nefrologia pediátrica. Método: o estudo foi realizado em duas etapas: revisão integrativa da literatura para elaboração do POP e validação por especialistas. A busca da literatura ocorreu nas bases de dados eletrônicas: PUBMED, SCOPUS, LILACS, BDENF. Após o levantamento bibliográfico deu-se a construção do POP que foi avaliado por especialistas. A análise foi realizada por meio do cálculo do Índice de Validade de Conteúdo (CVI). Resultados: como resultados da revisão integrativa foram selecionados nove estudos. A amostra dos especialistas foi composta por nove profissionais. O estudo foi avaliado em seis itens, os quais cinco apresentaram $C V I=1$ e um obteve $C V I=0,77$. Conclusão: a avaliação dos especialistas culminou na validação do POP, sendo sugeridas alterações que foram acatadas e discutidas com a literatura.

Descritores: Balanço Hídrico; Equilíbrio Hidroeletrolítico; Enfermagem; Protocolos; Pediatria.

\section{RESUMEN}

Objetivo: construir un Procedimiento Operativo Estándar (POE) sobre el balance hídrico, para ser utilizado por el equipo de salud en el cuidado al niño internado en una unidad de nefrología pediátrica. Método: el estudio fue realizado en dos etapas: revisión integradora de la literatura para la elaboración del POE y validación por especialistas. La búsqueda de la literatura ocurrió en las bases de datos electrónicos: PUBMED, SCOPUS, LILACS, BDENF. Después del levantamiento bibliográfico se dio la construcción del POE que fue evaluado por especialistas. El análisis fue realizado por medio del cálculo del Índice de Validez de Contenido (CVI). Resultados: como resultados de la revisión integradora fueron seleccionados nueve estudios. La muestra de los especialistas fue compuesta por nueve profesionales. El estudio fue evaluado en seis ítems, de los cuales cinco 
presentaron $C V I=1$ y uno obtuvo $C V I=0,77$. Conclusión: la evaluación de los especialistas culminó en la validación del POE, siendo sugeridas alteraciones que fueron acatadas y discutidas con la literatura.

Descriptores: Balance Hídrico; Equilibrio Hidroelectrolítico; Enfermería; Protocolos; Pediatria.

\section{INTRODUCTION}

Fluid balance is critical to the survival and homeostasis of organisms because they need to properly maintain fluid and electrolyte concentrations for the normal function of all cells. Fluid balance is regulated by neuroendocrine control systems and can be altered in disease states, such as in chronic kidney disease $\mathrm{e}^{(1-3)}$.

Patients with renal disorders usually present with hydro electrolyte imbalances and require careful evaluation and rigorous monitoring to identify signs of potential problems and prevent renal complications ${ }^{(4-5)}$.

Under normal conditions the ingestion of liquids is balanced by its elimination, avoiding the decrease or increase of its quantity in the organism. Adequate recording of this equation is of great importance for making therapeutic and care decisions ${ }^{(1,6)}$.

Thus, the water balance (WB) is the record of accurate measurements of fluids administered by intravenous and oral routes; and liquids excreted through the gastrointestinal and urinary routes, and their difference must be calculated ${ }^{(7)}$. When there is a divergence of this proportion, the presence of water imbalance is indicated. The daily performance of this action is essential in the care and early diagnosis of hydro electrolytic alterations ${ }^{(8)}$.

The nurse is the health professional who is 24 hours close to the patient and who has the best conditions to observe and identify changes in hydro electrolytic imbalances that compromise the various organs and systems of the organism ${ }^{(8)}$.

To do so, we have the water balance, whose results guide the pathways of care, identifying complications or disorders that can be prevented or minimized, through its adequate performance ${ }^{(9-10)}$.

However, the accurate recording of WB is not easy to obtain due to the difficulty in accounting for the losses, since it involves several people (nurses, technicians, patients and relatives) and lack of uniformity in the measurement and characterization of some drained contents ${ }^{(11)}$; besides the occurrence of incorrect filling of fields in the water balance form ${ }^{(9)}$.

As the realization of the WB has particularities it is necessary that there is a uniformity in its execution, by understanding how every process occurs in a systematized form. The Standard Operating Procedure (SOP) is an important resource that serves as a basis for standardizing activities, serving as a guide for services, with the objective of providing quality and safety ${ }^{(12)}$.

In view of the influence that the water balance has on the treatment and follow-up of the pediatric patient with renal impairment and the lack of standardization in performing this procedure, it is necessary to create an SOP to carry out the appropriate measurement and registration.

The work is considered important due to the lack of literature on the subject, to the lack of knowledge by the professionals about the complications of failing to perform the water balance and the devaluation of non-pharmacological measures ${ }^{(8-9)}$.
It is believed that the use of a standardized instrument to perform the water balance will guide the professionals involved in this care and, in this way, be able to decrease or avoid possible errors. It is expected that the use of SOP will contribute positively to the decision-making of health professionals and offer better assistance to the users of the service.

In view of these considerations, the following questions arose: what health care in the performance of water balance in children hospitalized? What should a water balance SOP be for children hospitalized?

\section{OBJECTIVE}

To construct a SOP on the water balance for health team in the care of the child hospitalized in a unit of pediatric nephrology.

\section{METHOD}

\section{Ethical aspects}

The research was approved by the Research Ethics Committee of Albert Sabin Children's Hospital. The study participants signed the Free and Clarified Consent Term.

\section{Design, place of study and period}

This is a methodological research, carried out from October 2015 to October 2016 at the nephrology unit of a pediatric public hospital in Fortaleza State.

The study was carried out in two stages: development of SOP and validation of the appearance and content of SOP.

\section{Population, sample; inclusion and exclusion criteria}

\section{Construction of the Standard Operating Procedure}

To develop SOP, it was necessary to perform an integrative review, following the steps: establishment of the hypothesis or question of the research; sampling or searching in the literature; categorization of studies; evaluation of the studies included in the review; interpretation of the results and synthesis of the knowledge or presentation of the review ${ }^{(13)}$.

In order to describe the steps of the water balance, the following guiding question was elaborated: what health care in the water balance of children hospitalized?

The scientific productions were searched in the following databases: SCOPUS, (LILACS) Latin American and Caribbean Literature in Health Sciences, (BDENF) Nursing Databases and in the search portal (PUBMED) Public/Publish Medline. Six articles were indexed in PUBMED, one in SCOPUS, one in LILACS and one in BDENF.

Inclusion criteria were complete research articles published in the Portuguese, Spanish or English languages and answer 
the guiding question of the study. Duplication was excluded. The descriptors used were: water balance, nursing, protocols, hydro electrolytic imbalance and their synonyms in English and Spanish. Initially, the water balance and nursing descriptors were associated, then the descriptors hydro electrolytic imbalance or protocols were added, with the help of Boolean operators and and or.

With the information obtained in the integrative review, SOP was built.

\section{Validation of Standard Operating Procedure}

For the SOP validation step, the opinion of experts in the area was considered. The selection of these professionals happened through the sampling of net or snowball. Thus, when a subject was found to fit the established eligibility criteria, he was asked to recommend other possible participants and, therefore, a convenience sample (14).

Nurses and physicians were invited to participate in the study due to their active participation in the patient's water control and to the water balance data influencing the established therapy.

The choice of experts was based on the expert attributes proposed by Jasper (1994), who are: having a specialized body of skills or knowledge, having extensive experience in a specific field of practice, having a high level of development for pattern recognition and being recognized by others for their expertise $\mathrm{e}^{(15)}$. Thus, the criteria of classification of the specialists were determined: $\mathrm{PhD}$ thesis developed on water balance and/or hydro electrolytic disturbance; Masters with dissertation developed on water balance and/or hydro electrolytic disturbance; Article published in the area of water balance and/or hydro electrolytic imbalance; Experience of at least two years in the area of nephrology in the care of patients with hydro electrolytic disorders; and certificate (specialization) in the area of health that has specific content with hydro electrolytic disorders. Professionals who met at least two of these criteria were included.

Specialists who reached the minimum score were invited to be part of the research, by means of an invitation letter via e-mail or in person. No expert refused to participate.

After the survey of validation studies in Brazil, samples were verified between five and nine specialists. Due to the lack of consensus in the literature about the number of people needed to compose the expert panel, we chose to use the sample of nine people, the highest number among the studies found ${ }^{(16-19)}$.

From the delivery of the data collection instrument and the SOP, a period of twenty days was established for the expert to perform the analysis, fill out the instrument and return it to the researcher via email or in person. However, two experts did not meet the initial deadline, being extended for another 15 days.

\section{Data analysis and statistics}

The answers to the questions contained in the validation instrument were presented in the form of a Likert scale. In this way, the evaluator scored the degree of agreement according to a five-point scale to avoid a neutral point ${ }^{(14)}$. The grading levels were: 1 = totally disagree, 2 = disagree, $3=$ do not agree, or disagree, $4=$ agree, $5=$ totally agree. It should be noted that a space was allocated for the evaluator to justify his/ her choice in case of disagreement.

Data for expert validation was compiled into a Microsoft Excel 2010 worksheet.

The Content Validation Index (CVI) was calculated, which verified the agreement among the specialists. The calculation used to assess agreement was the number of specialists who chose levels three and four divided by the total number of specialists. Values for $\mathrm{CVI}>0.80^{(14)}$.

\section{RESULTS}

The results are presented in two different phases. In the first one, the results regarding the process of construction of the SOP are described and in the second, the validation of the content of the SOP by specialists.

Process of construction of the Standard Operating Procedure

The bibliographical content survey, carried out through an integrative review of the literature, selected nine studies according to established criteria.

Concerning the year of publication, it was verified that the concern with this subject comes from 2002, maintaining constancy in the following years, reaching a greater number in 2011 with four publications.

It is observed with the results that the majority of the studies were international publications; seven are in English, one in Portuguese and one in Spanish. A study was authored by Brazilian nurses, published in an international journal. This data indicates that the scientific production in Brazil on water balance is also little explored.

It was verified that eight studies had descriptive correlational research as a methodological design and one of them, a research article. Based on these results, it is observed that the methodological designs of the studies present the following levels of evidence: one level V study and eight level VI studies ${ }^{(28)}$.

This demonstrates that the literature on water balance does not yet have sufficient numbers of studies that depict strong evidence, such as randomized controlled trials, considered relevant to Evidence-Based Practice.

Several objectives were listed by the researchers to address this theme, such as: evaluating water balance performance in a given service, evaluating the knowledge of health professionals about the theme, demonstrating the importance of taking stock and guiding how to perform it accurately (20-27).

According to the references, filling out the water balance report is the responsibility of the nursing team, and it is essential that it be done correctly, since these data will support the analysis of the patient's health status and the establishment of the care plan. It is up to the nurses to guide and supervise their team on the accomplishment of the water balance ${ }^{(9,20-21,26)}$.

It is indicated that the measurement and recording of all liquids infused into the patient during 24 hours, such as: intravenous infusion, bolus medications, circuit washing, blood and derivatives and TPN are performed. Also, all volumes that are administered to the patient via the gastric route, such as: water, oral diet, diet by probes, lavage of probes and oral medications ${ }^{(9,20,23,26)}$ should be recorded. 
Chart 1 - Arrangement of articles according to reference, methodological design, level of evidence and considerations

\begin{tabular}{|c|c|c|}
\hline Article & $\begin{array}{l}\text { Methodological } \\
\text { design/ } \\
\text { Evidence level }\end{array}$ & Results \\
\hline (9) & $\begin{array}{l}\text { Field Research/ } \\
\qquad I^{*}\end{array}$ & $\begin{array}{l}\text { It was verified that there is a lack of preparation of the nursing team, being necessary the development of actions } \\
\text { of continuing education, incentive to the participation of the team and reformulation of the water balance form. }\end{array}$ \\
\hline (20) & $\begin{array}{l}\text { Documentary } \\
\text { of qualitative } \\
\text { analysis } / \mathrm{VI}^{*}\end{array}$ & $\begin{array}{l}\text { Nursing annotations in relation to the water balance need to be reviewed and reordered, with a view to } \\
\text { improving the elaboration of the care plan, which should be systematized, individualized and humanized. }\end{array}$ \\
\hline (21) & $\begin{array}{l}\text { Literature } \\
\text { Review/ } N^{*}\end{array}$ & $\begin{array}{l}\text { Achieving optimal hydration is an essential part of holistic care for the serious clinical patient. Nursing care } \\
\text { is responsible for ensuring that water balance printouts are accurately and accurately recorded. }\end{array}$ \\
\hline (22) & $\begin{array}{l}\text { Descriptive, } \\
\text { exploratory/ } \\
\text { VI* }\end{array}$ & $\begin{array}{l}\text { The nursing team identified that entry and exit measures are useful and necessary for at-risk populations. } \\
\text { The lowa Model for Evidence-Based Practice guided the change in practice. }\end{array}$ \\
\hline (23) & $\begin{array}{l}\text { Descriptive/ } \\
\text { VI* }\end{array}$ & $\begin{array}{l}\text { Actions that must be performed in the measurement of fluid in and out are, among them: identifying the } \\
\text { patient's health conditions, recording the type and amount of all fluids the patient has lost and the way. }\end{array}$ \\
\hline (24) & $\begin{array}{l}\text { Case study/ } \\
\text { VI* }\end{array}$ & $\begin{array}{l}\text { Monitoring the fluid balance is something serious, which in many services is carried out in a casual and } \\
\text { imprecise manner. In the case presented the nurse was investigated by the professional conduct committee } \\
\text { and found guilty of her failure. }\end{array}$ \\
\hline (25) & $\begin{array}{l}\text { Descriptive/ } \\
\text { VI* }\end{array}$ & $\begin{array}{l}50 \% \text { of all medical records had fluid balance graphs. Intravenous infusion and urinary catheterization } \\
\text { accounted for almost } 70 \% \text { of the reason for FB recording. } 32 \% \text { of the water balance graphs were found } \\
\text { incomplete or incorrect. It was concluded that the nurse in the study context should be able to close charts. }\end{array}$ \\
\hline (26) & $\begin{array}{l}\text { Descriptive/ } \\
\text { VI* }\end{array}$ & $\begin{array}{l}\text { Fluid balance recording is an essential part of patient care and the responsibility of maintaining it rests with } \\
\text { the nurse. Employees should be trained to record fluid balance with the same importance of prescription } \\
\text { medications. }\end{array}$ \\
\hline (27) & $\begin{array}{l}\text { Descriptive/ } \\
\text { VI* }\end{array}$ & $\begin{array}{l}\text { It was found that there are significant differences between records with measurement errors, uncorrected } \\
\text { records and arithmetically corrected. }\end{array}$ \\
\hline
\end{tabular}

Note: * Levels of Evidence.

Often, bolus medications or circuit washings are not taken into account as they are taken as small volumes. However, the sum of all of them at the end of the day shows that much more volume is being infused than is computed ${ }^{(9,20)}$.

Ideally, the volumes already infused into the patient should be noted. In the case of the use of infusion pumps, they can be viewed and then reset from time to time (according to industry routine) to facilitate reading ${ }^{(9)}$.

Patient eliminations should also be measured and recorded, such as: gastric probe residue, diuresis, vomiting and drainage through measuring cups. Spontaneous diuresis and probes should be measured in measuring cups and diuresis and liquid stools in diapers that should be weighed. The volume of liquid in milliliters is proportional to the weight of the liquid measured in grams. There is no consensus among teams on how to quantify the volume of vomiting and drainage. When it is not possible to measure, it is indicated that they be mentioned in the observations and changes in nursing $(9,20-21,23,26)$.

Patient eliminations should be recorded, since the absence of evacuations leaves doubt about the intestinal function and water status of the patient, since the characteristics of the stool reflect the patient's hydration ${ }^{(20)}$.

The use of instruments such as measuring cups and scales is essential to facilitate the obtaining of accurate data of liquids ingested and eliminated by patients, considering the importance of real values. However, the measuring cup should not be used by more than one patient ${ }^{(20,23,26-27)}$.

The realization of the water balance should not be delegated to professionals who do not understand its importance. Besides evaluating the liquids eliminated, they should also be considered color and odor, being recorded in the medical record ${ }^{(23)}$.

The water balance records should be restricted to patients with an indication to perform it. And patients who are in waterfall should be evaluated systematically so that it is not done without necessity ${ }^{(25-26)}$.

Validation of the Standard Operating Procedure by specialists

After completing the literature review, the SOP was elaborated on water balance, which was submitted to the evaluation of a group of specialists for validation of the content, being the second phase of the research.

There was a predominance of female specialists (eight) and nurses (seven), ranging in age from 25 to 55 years and mean of 36.1 years.

With regard to professional qualification, two had a doctorate; six did masters; and specialization. This professional qualification was predominantly in post-graduate courses in nursing, since the majority of the participants were nurses. The medical professional who possessed specialization was in the form of medical residency in nephrology. 
In relation to the professional activity, four professionals were dedicated exclusively to the assistance, one worked in the assistance and teaching, three besides the assistance activities were team coordinators, and an assistant, teacher and team coordinator. The average time of professional performance was 13.3 years, in which four of the professionals had 0 to 9 years of work.

All the participants stated that they had experience in water balance in children, but none reported publication of scientific papers in this area. This data corroborates with the results of the literature review, demonstrating a shortage of publications on water balance.

Regarding the validity of the content of the constructed SOP, participants were asked to evaluate clarity and relevance in six aspects. These data can be evidenced in Table 1.

According to the table, items 1, 3, 4, 5 and 6 that refer to clarity, conciseness, graphic representation, language, materials and methods and levels of evidence have a maximum CVI Content Validity Index $=1$, whereas item 2 that refers to the applicability in all pediatric patients obtained CVI $<8.0$ among the specialists.

Item 2 was not considered valid, because two experts classified as "I do not agree, nor disagree" and "disagree". The rationale indicated by the experts reveals that SOP needs to be reviewed for use in a pediatric intensive care unit and that considerations are needed to address the neonatal public. Evaluating that the protocol was developed to be used in a pediatric nephrology hospitalization unit, it is concluded that the SOP was considered valid by the specialists.

However, experts were asked to record the recommendations and corrections they deemed necessary. Thus, pertinent suggestions have been made that have been adopted for the improvement of SOP.

A chart containing the items assessed, the problems identified and the respective suggested alterations was elaborated (Chart 2) to check the topics evaluated by the experts that recommended changes.

Table 1 - Distribution of content validity indexes for the evaluated aspects, Fortaleza, Ceará State, Brazil, 2016

\section{Aspects evaluated}

CVI*

1. The Standard Operating Procedure is clear and concise and its graphical representation allows the rapid assimilation of the concepts 1.0 and the organization of the steps.

2. The Standard Operating Procedure can be applied to all pediatric users.

3. The language used is understandable for health professionals who will use it.

4. The Standard Operating Procedure presents the materials and methods necessary for the water balance to be carried out properly.

5. The Standard Operating Procedure allows for the recognition of the executors of the actions.

6. The content of the Standard Operating Procedure is in accordance with the scientific literature and may be considered as ready for use or its use may be considered.

Note: *Content Validity Index.

Chart 2 - Demonstration of the items evaluated by the experts, problems identified and respective alterations suggested, according to protocol evaluation

\begin{tabular}{|c|c|c|}
\hline Items evaluated & Problems identified & Alterations \\
\hline $\begin{array}{l}\text { Assignments of } \\
\text { professionals }\end{array}$ & $\begin{array}{l}\text { To better establish the role of the } \\
\text { technician and the nurse. }\end{array}$ & $\begin{array}{l}\text { Beside the described procedure create a column to determine the } \\
\text { professional responsible for exercising it. }\end{array}$ \\
\hline $\begin{array}{l}\text { Order of } \\
\text { procedures }\end{array}$ & $\begin{array}{l}\text { Alternation in the description of } \\
\text { procedures between liquids eliminated } \\
\text { and ingested. }\end{array}$ & $\begin{array}{l}\text { To describe first all the procedures for liquids then discarded for } \\
\text { liquids ingested. }\end{array}$ \\
\hline $\begin{array}{l}\text { Diuresis } \\
\text { elimination routes }\end{array}$ & Absence of route of elimination. & $\begin{array}{l}\text { To determine the urethral diuresis elimination route, indwelling } \\
\text { catheter, intermittent catheter, catheterization by mitrofanoff, } \\
\text { cystostomy, ureterostomy and pelvicostomy (if bilateral, specify right } \\
\text { and left volume). }\end{array}$ \\
\hline $\begin{array}{l}\text { Eliminations from } \\
\text { diapering patients }\end{array}$ & $\begin{array}{l}\text { Lack of understanding of the activity: } \\
\text { Weighing the diaper before giving the patient, } \\
\text { after the diuresis weigh again, subtract the } \\
\text { value of the dry diaper, the result should be } \\
\text { recorded on the water balance sheet. }\end{array}$ & $\begin{array}{l}\text { To weigh the dry diaper before offering it to the patient, after diuresis } \\
\text { weigh it again and subtract the value of the dry diaper, the result } \\
\text { found should be recorded on the water balance sheet. }\end{array}$ \\
\hline $\begin{array}{l}\text { Consistency of } \\
\text { bowel movements }\end{array}$ & $\begin{array}{l}\text { To offer diapers to patients with liquid } \\
\text { stools. }\end{array}$ & To modify for patients presenting with liquid or diarrheal stools. \\
\hline Infusion pumps & To reset the infusion pumps every 6 hours. & To reset the infusion pumps as prescribed by the water balance. \\
\hline
\end{tabular}


Chart 3 - Items included as suggested by experts

\begin{tabular}{|l|l|}
\hline Weight measurement & Recording the patient's weight before and after the closing of the water balance. \\
\hline Peritoneal dialysis or hemodialysis & $\begin{array}{l}\text { Checking and recording losses or gains from peritoneal dialysis or hemodialysis of patients undergoing } \\
\text { such therapy. }\end{array}$ \\
\hline Colostomy and ileostomy & Measuring and recording the volume of liquid or diarrheal stools eliminated by colostomy or ileostomy. \\
\hline
\end{tabular}

According to the chart, the items of the SOP indicated by the specialists were: two made reference on the attributions of the professionals; one, on the order of the proceedings; two discussed ways of eliminating diuresis; two, the eliminations of the patient using diapers; two, the consistency of bowel movements; one, the infusion pumps.

Considerations to be added to SOP were also suggested. According to experts, they would be: one suggested weight gauging; one, peritoneal dialysis and hemodialysis; and two, colostomy and ileostomy.

\section{DISCUSSION}

Among the experts, two suggested that the duties of the technician and the nurse should be more clearly established. Nurses, as responsible for the nursing team, should guide all care besides not exempt from any action related to the water balance, since these data are important in the formulation of a later nursing diagnosis and in the planning of actions ${ }^{(9)}$.

In the construction of SOP, the activities were divided between nurses and nursing technicians, due to the need for service organization and understanding of the roles. However, it is suggested that the executor of the activity be responsible for recording it in order to obtain accuracy of the information.

It was advised by one of the specialists that all the procedures for measuring and recording the liquids eliminated and later for liquids ingested should be described first. This observation is considered relevant because the best way to start a standardization is through the understanding of how the whole process occurs in a systematized representation, which characterizes $\mathrm{SOP}^{(12)}$.

Regarding diuresis elimination pathways, two specialists reinforced urethral elimination route, indwelling catheter, intermittent catheter, catheterization by mitrofanoff, cystostomy, ureterostomy and pelvicostomy (if bilateral, specify left and right volume). Accurate recording of data is important to contribute to the establishment of the individualized care plan, aiming at the real needs of the patient ${ }^{(8)}$.

It was recommended by two of the experts to reformulate the text that guides the registry of the eliminations present in diapers. To obtain the volume of liquids disposed in diapers it is necessary for the diaper to be weighed and dried to obtain a value which will thereafter be subtracted from the value of the heavy diaper with the liquids removed. For a better understanding the text has been improved ${ }^{(27)}$.

The use of the term, liquid stools, was considered vague by one of the experts, who suggested adding diarrhea. In one study it was observed that diarrheal intestinal eliminations were not measured and several times were not mentioned in nursing observations and nursing evolutions. The lack of registration of these data results in an always positive balance sheet, which does not reflect reality ${ }^{(9)}$.

The advice to zero the infusion pump every six hours has not been recommended by one of the specialists, since the infusion pumps must be zeroed according to the balance prescription.

Infusion pumps are electronic devices used to infuse volumes of solutions accurately and preset, as well as storing infusion data $^{(28)}$. Another study recommended that the pumps should be reset from time to time, according to the industry routine ${ }^{(9)}$.

There were suggestions for adding three items to the protocol, which are: daily weight gauging; record of losses and gains from peritoneal dialysis and hemodialysis; and measuring and recording the volume of liquid stools or diarrhea by colostomies and ileostomies.

According to one of the specialists, the weight of the patient should be recorded before and after the closing of the water balance. Changes in weight in the short period are largely due to changes in the body's total water. Knowledge of the intensity and direction of this parameter may exert great relevance in the diagnosis and treatment of complex disorders of the electrolyte balance ${ }^{(22)}$.

It was also recommended by a specialist to record the losses and gains of patients on hemodialysis or peritoneal dialysis. These procedures are performed to remove uremic liquids and residual products from the body when the kidneys fail to do so, and the rigorous water balance is important ${ }^{(4)}$.

Finally, the registry of colostomy and ileostomy eliminations was suggested by one of the specialists. The registry of colostomy eliminations should be recorded in the water balance as all patient losses ${ }^{(26)}$.

\section{Study limitations}

It is important to emphasize, as a limitation of the study, the difficulty in finding articles that deal with the Water Balance theme and especially with regard to national productions.

\section{Contributions to the Nursing}

From the care described in the SOP, considered essential for water balance, the importance of the nursing team for the good performance of this activity was evident. It is hoped to have contributed with a nursing technology that guides the professionals in the assistance to the patients in need of water balance.

\section{CONCLUSION}

The integrative review of the literature to raise data for the construction of SOP was fundamental to guide its structuring. The productions focused on the definition of water balance, 
the role of nursing in the development of this action, the routes of ingestion and elimination of liquids, measurement of content and adequate recording of water balance data.

After the construction, the SOP was submitted to the validation of appearance and content by nine specialists. The evaluation of the specialists culminated in the validation of the SOP, suggesting some changes that were accepted and discussed with the literature. However, according to experts, SOP needs to be revised to be applied in pediatric intensive care unit patients.
After the validation of the content of the SOP, it is recommended its clinical validation in the assistance practice in pediatric nephrology, aiming to offer greater reliability and safety to patients and professionals.

It is concluded that the water balance is a complex activity that requires knowledge of the nursing team for its adequate execution. It is known that the present study certainly does not cover all gaps in care. Thus, it is suggested that more studies be carried out in order to increase the production of knowledge about the subject.

\section{REFERENCES}

1. Coble JP, Grobe JL, Johnson AK, Sigmund CD. Mechanisms of brain renin angiotensin system-induced drinking and blood pressure: importance of the subfornical organ. Am J Physiol Regul Integr Comp Physiol [Internet]. 2015 [cited 2016 Oct 25];308(4):38-49. Available from: https://www.physiology.org/doi/full/10.1152/ajpregu.00486.2014

2. Stanhewicz AE, Kenney WL. Determinants of water and sodium intake and output. Nutr Rev [Internet]. 2015 [cited 2016 Oct 25];73(2):73-82. Available from: https://academic.oup.com/nutritionreviews/article-lookup/doi/10.1093/nutrit/nuv033

3. Benton D, Braun H, Cobo JC, Edmonds C, Elmadfa I, El-Sharkawy A, et al. Executive summary and conclusions from the European Hydration Institute expert conference on human hydration, health, and performance. Nutr Rev [Internet]. 2015 [cited 2017 Oct 25];73(2):148-50. Available from: https://academic.oup.com/nutritionreviews/article-lookup/doi/10.1093/nutrit/nuv056

4. Sampaio RMM, Coelho MO, Pinto FJM, Osteme EPR. Epidemiological profile of patients with nephropathy and the difficulties in access to treatment. Rev Bras Promoç Saúde [Internet]. 2013 [cited 2016 Oct 25];26(1):95-101. Available from: http://www. redalyc.org/pdf/408/40827988014.pdf

5. Pereira ER, Ribeiro IML, Ruas EFG, Silva PLN, Gonçalves RPF, Diamantino NAM. Análise das principais complicações durante a terapia hemodialítica em pacientes com insuficiência renal crônica. Rev Enferm Centro O Min[Internet]. 2014 [cited 2016 Oct 25];4(2):1123-34. Available from: http://www.seer.ufsj.edu.br/index.php/recom/article/view/603/747P

6. Langer T, Santini A, Scotti E, Regenmortel NV, Malbraind MLNG, Caironi P. Intravenous balanced solutions: from physiology to clinical evidence. Anaesthesiol Intensive Ther [Internet]. 2015 [cited 2016 Oct 25];47:78-88. Available from: https://journals. viamedica.pl/anaesthesiology_intensivetherapy/article/view/AIT.a2015.0079/30285

7. Perrier ET, Buendia-Jimenez I, Vecchio M, Armstrong LE, Tack I, Klein A. Twenty-Four-Hour urine osmolality as a physio logical index of adequate water intake. Dis Markers [Internet]. 2015 [cited 2016 Oct 25];2015:1-8. Available from: https://www.ncbi.nlm. nih.gov/pmc/articles/PMC4381985/pdf/DM2015-231063.pdf

8. Oliveira SKP, Guedes MVC, Lima FETL. Balanço hídrico na prática clínica de enfermagem unidade coronariana. Rev Rene [Internet]. 2010 [cited 2015 Oct 10];11(2):112-20. Available from: http://www.repositorio.ufc.br/bitstream/riufc/4643/1/2010 art_fetlima2.pdf

9. Marques SFS, Souza LM, Beleza LO. Balanço Hídrico em recém-nascidos com extremo baixo peso: o conhecimento dos profissionais de enfermagem. Comun Ciênc Saúde [Internet]. 2011 [cited 2015 Oct 10];22(1):41-5. Available from: http://bvsms. saude.gov.br/bvs/periodicos/revista_ESCS_v22_n1_a07_balanco_hidrico_recem_nascidos.pdf

10. Lee J, Louw E, Niemi M, Nelson R, Mark RG, Celi LA, et al. Association between fluid balance and survival in critically ill patients. J Intern Med [Internet]. 2015 [cited 2016 Oct 25];277(4):468-77. Available from: https://www.ncbi.nlm.nih.gov/pmc/articles/ PMC4265574/pdf/nihms-603155.pdf

11. Davies H, Leslie G, Morgan D. Effectiveness of daily fluid balance charting in comparison to the measurement of body weight when used in guiding fluid therapy for critically ill adult patients: a systematic review protocol. JBI Database System Rev Implement Rep [Internet]. 2015 [cited 2016 Oct 10];13(3):111-23. Available from: http://journals.Iww.com/jbisrir/Fulltext/2015/13030/ Effectiveness_of_daily_fluid_balance_charting_in.10.aspx

12. Walter RR, Gehlen MH, Ilha S, Zamberlan C, Freitas HMB, Pereira FW. Standard operating procedure in the hospital context: the nurses perception. Rev Pesqui Cuid Fundam[Internet]. 2016 [cited 2017 Feb 25];8(4):5095-100. Available from: http://www.seer. unirio.br/index.php/cuidadofundamental/article/view/4413/pdf

13. Whittemore R, Knafl K. The integrative review: updated methodology. J Adv Nurs [Internet]. 2005[cited 2017 Feb 25];52(5):54653. Available from: https://www.ncbi.nlm.nih.gov/pubmed/16268861

14. Polit DF, Beck CT. Fundamentos de pesquisa em enfermagem: avaliação de evidências para a prática de enfermagem. 7 ed. Porto Alegre: Artmed; 2011.

15. Jasper A. Expert: a discussion of the implications of the concept as used in nursing. J Adv Nurs. 1994;20(4):769-76.

16. Toso BRGO, Vieira CS, Valter JM, Delatore S, Barreto GMS. Validation of newborn positioning protocol in Intensive Care Unit. Rev 
Bras Enferm[Internet]. 2015 [cited 2016 Oct 10];68(6):1147-53. Available from: http://www.scielo.br/pdf/reben/v68n6/en_00347167-reben-68-06-1147.pdf

17. Marinho PML, Campos MPA, Rodrigues EOL, Gois CFL, Barreto IDC. Construction and validation of a tool to assess the use of light technologies at Intensive Care Units. Rev Latino-Am Enferm[Internet]. 2016 [cited 2017 Feb 13];24:1-8. Available from: http://www.scielo.br/pdf/rlae/v24/0104-1169-rlae-24-02816.pdf

18. Dini AP, Guirardello EB. Pediatric patient classification system : improvement of an instrument. Rev Esc Enferm USP[Internet]. 2014[cited 2015 Oct 25];48(5):787-93. Available from: http://www.scielo.br/pdf/reeusp/v48n5/0080-6234-reeusp-48-05-787.pdf

19. Teles LMR, Oliveira AS, Campos FC, Lima TM, Costa CC, Gomes LFS, et al. Development and validating an educational booklet for childbirth companions. Rev Esc Enferm USP [Internet]. 2014 [cited 2015 Oct 10];48(6):977-84. Available from: http://www. scielo.br/pdf/reeusp/v48n6/0080-6234-reeusp-48-06-0977.pdf

20. Oliveira SKP, Guedes MVC, Lima FETL. Nursing's records to the control of hydric balance. Rev Enferm UFPE[Internet]. 2010 [cited 2015 Oct 10];4(1):68-74. Available from: https://periodicos.ufpe.br/revistas/revistaenfermagem/article/view/5834/5091

21. Shepherd A. Measuring and managing fluid balance. Nurs Times [Internet]. 2011 [cited 2015 Oct 12];107(28):12-6. Available from: https://www.nursingtimes.net/Journals/1/Files/2011/8/1/Fluid\%20balanceCorr.pdf.pdf

22. Alexander L, Allen D. Establishing an evidence-based inpatient medical oncology fluid balance measurement policy. Clin J Oncol Nurs [Internet]. 2011[cited 2015 Oct 12];15(1):23-5. Available from: https://cjon.ons.org/cjon/15/1/ establishing-evidence-based-inpatient-medical-oncology-fluid-balance-measurement-policy

23. Mcconnell EA. Measuring fluid intake and output. Nurs[Internet]. 2002 [cited 2015 Oct 12];32(7):17. Available from: http:// journals.Iww.com/nursing/Citation/2002/07000/Measuring_fluid_intake_and_output.12.aspx

24. Castledine G. Nurse who did not keep accurate fluid balance records and was rude. Br J Nurs [Internet]. 2003 [cited 2015 Oct 12];12(12):717. Available from: https://doi.org/10.12968/bjon.2003.12.12.11333

25. Chung LH, Chong S, French P. Theefficiency offluid balancecharting: an evidence-based management project.J Nurs Manag [Internet]. 2002[cited 2015 Oct 12];10:103-13. Available from: http://onlinelibrary.wiley.com/doi/10.1046/j.0966-0429.2001.00296.x/pdf

26. Scales K, Pilsworth J. The importance of fluid balance in clinical practice. Nurs Stand [Internet]. 2008 [cited 2015 Oct 12];47(22):5057. Available from: http://journals.rcni.com/doi/pdfplus/10.7748/ns2008.07.22.47.50.c6634

27. Alejandro AG, Buey JAC, Camina RMM. Estudio para la disminución de errores en el registro de los balances hídricos de pacientes críticos ingresados em una unidad de cuidados intensivos. Enferm Intensive [Internet]. 2005[cited 2015 Oct 12];16(3):100-9. Available from: http://www.elsevier.es/es-revista-enfermeria-intensiva-142-articulo-estudio-disminucion-errores-el-registro-13077404

28. Melnik BM, Fineout-Overholt E. Making the case evidence-based practice. In: Melnyk BM, Fineout-Overholt E. Evidence-based practice in nursing \& healthcare: a guide to best practice. Philadelphia: Lippincot Williams \& Wilkins; 2005. p.3-24. 